\title{
LOGÍSTICA REVERSA: QUAL É O PAPEL DOS MUNICÍPIOS NO CENÁRIO DA POLÍTICA NACIONAL DE RESÍDUOS SÓLIDOS?
}

Flávia Maria Gonçalves

Promotora de Justiça do Estado de São Paulo - Grupo de Atuação e Defesa do Meio Ambiente - Núcleo Baixada Santista (GAEMA/BS); Especialização em Direito Processual Civil pela Universidade Católica de Santos (UNISANTOS); Mestranda em Direito da Saúde: Dimensões Individuais e Coletivas pela Universidade Santa Cecília (UNISANTA).

famagon67@gmail.com

\section{Renata Salgado Leme}

Advogada. Professora da Universidade Santa Cecília (UNISANTA). Doutora em Filosofia e Teoria Geral do Direito/USP.

renataleme@aasp.org.br

\begin{abstract}
RESUMO: O crescimento da população e o consumo desenfreado como um reflexo de uma economia em constante desenvolvimento exige que a prevenção, a geração e a destinação dos resíduos sólidos sejam incorporadas como práticas de uma gestão pública e privada de modo a se garantir a eficiência da coleta dos resíduos sólidos urbanos e, via de consequência, uma sadia qualidade de vida das pessoas nas cidades, na medida em que resíduos dispostos de maneira irregular causam sérios danos ao meio ambiente e à saúde pública. Este artigo pretende enfocar como os Municípios devem se posicionar frente aos aspectos específicos do marco regulatório da Lei Federal 12.305/2010 e Decreto Federal 7.4040/2010, relativos à logística reversa, um dos principais instrumentos da Política Nacional de Resíduos Sólidos, relacionada à responsabilidade compartilhada pelo ciclo de vida dos produtos listados no artigo 33 da referida lei, buscando-se sejam os mesmos reutilizáveis e recicláveis, como um bem econômico e de valor social, gerador de trabalho e renda e promotor de cidadania.
\end{abstract}

PALAVRAS-CHAVE: Política Nacional de Resíduos Sólidos. Resíduos Sólidos. Responsabilidade Compartilhada. Logística reversa. Municípios.

Reverse logistics: what is the role of municipalities in the national solid waste policy scenario?

ABSTRACT: The growth of the population and the rampant consumption as a reflection of an economy that is in constant development require that prevention, the generation and disposal of solid wastes are incorporated as practices of public and private management in order to ensure the efficiency of the collection of municipal solid waste and, as a result, route a healthy quality of life for people in the cities to the extent that residues arranged irregularly cause serious damage to the environment and public health. This article will focus on how the municipalities should position itself in relation to the specific aspects of the regulatory framework of 12,305/ 2010 Federal law and Federal Decree 7.4040/2010 concerning the reverse logistics, one of the main instruments of the Brazilian solid waste Policy, related to shared responsibility for the lifecycle of the products listed in article 33 of the Act, seeking itself are the same reusable and 
Logística reversa: qual é o papel dos municípios no cenário da Política Nacional de Resíduos Sólidos?

recyclable as a good economical and social value work and income generator and promoter of citizenship

KEYWORDS: National Solid Waste Policy. Solid Waste. Shared Responsibility. Reverse logistic. Counties.

\section{INTRODUÇÃO}

É fato notório que o crescimento das cidades não foi acompanhado de um aumento da capacidade de gestão dos problemas que a concentração de pessoas nas cidades acarreta, traduzido pela oferta de infraestrutura e de serviços urbanos adequados. A qualidade de vida das presentes e futuras gerações depende de políticas públicas, de diferentes setores da administração, que levem em conta os aspectos ambientais e de saúde pública, intimamente ligada ao atendimento de demandas relativas ao saneamento básico, que incluem o abastecimento de água potável, a coleta e tratamento de esgoto sanitário, a estrutura para a drenagem urbana e o sistema de gestão e manejo dos resíduos sólidos, sendo este último tema o eleito como ponto de partida para reflexões mais aprofundadas.

Segundo o último Censo divulgado pelo IBGE em $1^{\circ}$ de julho de 2014, o Brasil registrou uma população estimada de 202.768.562/hab. ${ }^{1} \mathrm{O}$ referido Instituto também divulgou a tabela de projeções do crescimento populacional, apontando uma população estimada de 212.077.375/hab. em 2020; de 223.126.917/hab. em 2030 e 228.153.204/hab. em 2040. ${ }^{2}$ Por outro lado, ao longo dos anos a distribuição desta população nas áreas rurais e urbanas vem se alterando substancialmente. Na década de 1960 o Estado de São Paulo, por exemplo, tinha uma população urbana de $8.149 .979 /$ hab. e uma população na área rural de 4.824.720/hab. Já no último Censo de 2010, a população urbana era de 39.585.251/hab. e a rural de 1.676.948/hab.

A ABRELPE - Associação Brasileira de Empresas de Limpeza Pública e Resíduos Especiais divulga periodicamente um relatório intitulado "O panorama dos resíduos sólidos no Brasil", sendo a última versão publicada do ano de 2014, contendo, portando, dados relativamente atualizados, levando em conta informações coletadas em cerca de 400 Municípios brasileiros. $^{3}$

Pela síntese analítica das informações divulgadas pela ABRELPE, a mesma apontou que a geração de resíduos sólidos urbanos (RSU) nestes 400 Municípios pesquisados foi de 78,6 milhões de toneladas, o que representou um aumento de 2,9\% em relação ao ano de 2013, índice superior à taxa de crescimento populacional no país, no mesmo período, que foi de $0,9 \%$.

Já a coleta dos RSU em 2014 também teve um aumento de 3,20\% relativamente a 2013, sendo que a comparação desse índice com o crescimento da geração de RSU mostrou uma discreta evolução da cobertura dos serviços de coleta de RSU, a qual atingiu um total de 71.260.045 toneladas coletadas no ano. Houve também um aumento da coleta per capita de 2,34\% entre 2013 e 2014, com 351,49 kg/hab/ano.

Os dados revelaram, entretanto, que cerca de 7 milhões de toneladas de RSU gerados nestes 400 Municípios pesquisados deixaram de ser coletados e, consequentemente, tiveram

\footnotetext{
1 http://www.ibge.gov.br/home/estatistica/populacao/estimativa2014/default.shtm. Acesso em: 25 jul. 2017.

2 http://www.ibge.gov.br/home/estatistica/populacao/projecao_da_populacao/2013/default_tab.shtm. Acesso em: 25 jul. 2017.

3 http://www.abrelpe.org.br/panorama_envio.cfm?ano=2014, acesso em 25.jul.2017.
} 
destino impróprio, o que nos sinaliza que o problema evolvendo todos os Municípios brasileiros é muito maior.

Outro dado relevante disponibilizado pelo Ministério do Meio Ambiente (2012), através da versão do Plano Nacional de Resíduos Sólidos e que atualmente está em processo de revisão, é sobre o diagnóstico que contém números alarmantes.

A estimativa de composição gravimétrica dos resíduos sólidos urbanos coletados no Brasil, de acordo com a última pesquisa oficial (MMA, 2012, p. 10-14), é de 31,90\% de materiais recicláveis $(58.527,40 \mathrm{t} / \mathrm{d}), 51,4 \%$ de matéria orgânica $(94.335,10 \mathrm{t} / \mathrm{d})$ e $16,70 \%$ para "outros" resíduos $(30.618,90 \mathrm{t} / \mathrm{d})$, totalizando $100 \%$ e correspondendo a $183.481,50$ t/d. Já a média nacional de produção de resíduos sólidos por habitante é de $1,1 \mathrm{~kg} / \mathrm{hab}$./dia. Fechando os números, o diagnóstico também apontou como o país tem disposto os resíduos sólidos, ou seja, $58,3 \%$ do que é gerado são destinados para aterros sanitários; $19,4 \%$ são destinados para aterros controlados e 19,8\% são destinados para "Lixões". Apenas 2,5\% dos resíduos coletados têm outras destinações e deste percentual apenas $1,4 \%$ dos resíduos coletados são encaminhados para a reciclagem.

Para ajudar a reverter estes números, em 02 de agosto de 2010 foi publicada a Lei Federal 12.305/2010 que instituiu a Política Nacional de Resíduos Sólidos (PNRS), contendo princípios estruturantes, objetivos, instrumentos e diretrizes aplicáveis a uma gestão eficiente dos resíduos sólidos, dotando o país de uma política clara e abrangente para um setor até então em completo descontrole. Logo em seguida, em 23 de dezembro de 2010 foi editado o Decreto Federal 7.404/2010 que veio a complementar a PNRS e criou o Comitê Interministerial da PNRS e o Comitê Orientador para a implementação dos Sistemas de Logística Reversa, que se propõe seja o objeto principal de abordagem deste artigo e a participação dos Municípios neste processo.

Em síntese, o artigo foi baseado em leitura de leis, artigos, livros e revistas especializados na temática ambiental enfocada, como ainda se buscaram dados de pesquisa sobre população, estimativa de crescimento populacional, estimativa de coleta e destinação ambientalmente correta dos resíduos sólidos urbanos, ressaltando-se a importância da gestão integrada dos resíduos sólidos pelos Municípios, seus benefícios de ordem social, ambiental e de saúde pública. Posteriormente o artigo se aprofundou na análise legal de um dos instrumentos de implantação da Política Nacional de Resíduos Sólidos, qual seja a Logística Reversa para, em seguida, enfrentar a seguinte questão: Os Municípios brasileiros podem exigir dos responsáveis legais a implantação em seus territórios da Logística Reversa, independentemente de ações prévias por parte da União, através de acordos setoriais, ou estados-membros, através dos termos de compromissos?

\section{A GeSTÃo ADEQUAdA dOS RESíduOS SÓlidos E SEUS BENEFÍCIOS SOCIAIS, AO MEIO AMBIENTE E SAÚDE PÚBLICA}

Desde a edição da Lei de Política Nacional de Meio Ambiente (Lei Federal 6.839/81), o Brasil vem gradualmente inserindo a temática ambiental na legislação e nas políticas públicas, sendo que a sustentabilidade e a educação ambiental nos dias de hoje precisam fazer parte da agenda dos setores público e privado.

A Constituição Federal estabelece no artigo 225 "caput" que "Todos têm direito ao meio ambiente ecologicamente equilibrado, bem de uso comum do povo e essencial à sadia 
Logística reversa: qual é o papel dos municípios no cenário da Política Nacional de Resíduos Sólidos?

qualidade de vida, impondo-se ao poder público e à coletividade o dever de defendê-lo e preservá-lo para as presentes e futuras gerações...".

Nesse contexto não há como negar que a escassez de recursos ambientais e o consumo desenfreado da população exigem que a prevenção, a geração e a destinação dos resíduos sólidos sejam aspectos fundamentais para a manutenção da qualidade da limpeza urbana e, via de consequência, do bem-estar e da sadia qualidade de vida das pessoas nas cidades.

Neste contexto, a importância do marco regulatório inaugurado no País com as edições da Lei Federal 12.305/2019 e Decreto Federal 7.404/2010, enfatizando Milaré (2013, p. 1152) em sua obra que:

\begin{abstract}
A Política Nacional de Resíduos Sólidos preencheu uma importante lacuna no arcabouço regulatório nacional. Essa iniciativa é o reconhecimento, ainda que tardio, de uma abrangente problemática ambiental que assola o País, problemática esta de proposições desconhecidas, mas já com diversos episódios registrados em vários pontos do território nacional, e que tem origem exatamente na destinação e disposição inadequadas de resíduos e consequente contaminação do solo, além da dificuldade de identificação dos agentes responsáveis. Esses registros indicam a gravidade de situações de contaminação do solo e das águas subterrâneas, com risco efetivo à saúde pública e à biota, além do comprometimento do uso dos recursos naturais em benefício da sociedade.
\end{abstract}

No mesmo sentido, ressaltaram Silva Filho e Soler (2012, p. 13) na obra Gestão de Resíduos Sólidos:

Esses diplomas normativos impuseram aos setores privado e público uma nova dinâmica a ações, medidas e procedimentos de gerenciamento ambientalmente adequado de resíduos sólidos. Inobstante as implicações jurídicas, técnicas e institucionais relacionadas à gestão de resíduos não se tratarem de agenda recente, vislumbra-se para esta década uma verdadeira revolução nos modos de produção, gestão pública e cultura cidadã em prol do desenvolvimento sustentável. Esse período de expectativas e tendências poderá ser marcado pela reengenharia dos processos produtivos realizado pelo seguimento empresarial, compromisso do poder público com a eliminação definitiva dos deletérios lixões, bem como pelo pacto coletivo da sociedade brasileira de revisitar padrões de consumo e ditames educacionais e culturais.

De fato, a PNRS trouxe como grandes propósitos a adequada gestão ${ }^{4}$ e gerenciamento ${ }^{5}$ dos resíduos sólidos, de forma compartilhada e integrada entre o setor público e privado. Estes conjuntos de ações trazem inegáveis benefícios para o meio ambiente e coletividade.

Conforme os dados acima indicados no Plano Nacional de Resíduos Sólidos, cerca de 19,8\% dos resíduos gerados no país são dispostos nos chamados "lixões". Isto representa cerca de 36.329,33 t/dia de resíduos dispostos sobre o solo, sem qualquer tratamento, sem medidas de proteção ao meio ambiente ou à saúde pública.

Comentando sobre este problema, Fernando Pagani Possamai (2007, p. 171-179) alerta que:

"Causas inocentes, como a falta de opção ou de consciência técnica, ou "menos inocentes", como a má vontade política para resolver a destinação final dos resíduos sólidos, fazem com que o lixo seja disposto clandestinamente, causando dire-

4 Conjunto de ações voltadas para a busca de soluções para os resíduos sólidos, de forma a considerar as dimensões política, econômica, cultural e social, com controle social e sob a premissa do desenvolvimento sustentável (art. $3^{\circ}$, X, da Lei 12.305/10).

5 Conjunto de ações exercidas, direta oi indiretamente, nas etapas de coleta, transbordo, tratamento e destinação final ambientalmente adequada dos resíduos sólidos e disposição final ambientalmente adequada dos rejeitos, de acordo com o Plano Municipal de Gestão Integrada de Resíduos Sólidos (PMGIRS) ou com o Plano de Gerenciamento de Resíduos Sólidos (art. $3^{\circ}$, X da Lei 12.305/10). 
tamente poluição do ar, do solo e das águas superficiais e subterrâneas. Considerando a saúde pública, os vetores de doenças são tanto os macro vetores (cachorros, gatos, ratos, urubus, pombos e outros), como os micro vetores (moscas, mosquitos, bactérias, fungos e outros)".

As consequências desses danos ambientais ao meio ambiente natural ou urbano, causam, de maneira geral, problemas de saúde no homem, seja através de agentes patogênicos ou substâncias químicas, seja influindo no seu bem estar (SISINNO, 2000).

A poluição causada no solo por resíduos sólidos dispostos de forma inadequada pode se dar por substâncias químicas e por compostos produzidos a partir de matéria orgânica, cujos teores de metais pesados em concentrações elevadas podem comprometer suas propriedades, o que, via de consequência, também contamina as águas superficiais e subterrâneas (PEREIRA NETO \& STENTIFORD, 1992 apud SISINNO, 2000).

Por óbvio que o solo e as águas nestas condições poderão ficar comprometidos para uso e consumo humano por longo tempo e a exposição do homem poderá ocorrer por ingestão de água ou consumo de animais e vegetais aquáticos originados de corpos d'água superficiais contaminados. Vegetais irrigados com água contaminada por chorume também poderão causar problema de saúde ao homem.

Prossegue o texto de Pagani Possamai (2007, p. 171-179):

\begin{abstract}
Destacando o aspecto de poluição das águas, vale lembrar que nos lixões o chorume é um dos principais elementos impactantes, sendo originado da decomposição da matéria orgânica contida no lixo, associada aos líquidos percolados ali existentes. Se o solo sob o lixão for permeável, o chorume poderá atingir o lençol freático, poluindo esse recurso hídrico. A geração de chorume pode alongar-se além de quinze anos após o final da deposição de lixo, dependendo de vários fatores. Um exemplo brasileiro é um aterro na cidade de São Paulo, com mais de quinze anos, que acumula todos os dias aproximadamente 500 mil litros de chorume. Substâncias químicas encontradas tanto em resíduos industriais como no chorume podem ser assimiladas por vegetais, não sendo recomendada a utilização dessas culturas para alimentação.
\end{abstract}

Não podemos também esquecer que resíduos coletados de forma imprópria e depositados de maneira inadequada, como em valas, rios, canais, poderão comprometer o escoamento das águas em épocas de chuvas fortes e causar transtornos como enchentes e surtos de leptospirose.

Outro aspecto importante e que diz respeito à poluição do ar é que as populações que vivem em locais próximos à disposição de resíduos podem sofrer distúrbios respiratórios causados pela poeira em suspensão e o cheiro desagradável e irritante de substâncias voláteis, causando cefaleia e náuseas. A poluição do ar também poderá ser responsável por problemas de visão, como irritação e inflamação da mucosa ocular (ACURIO et al., 1977 apud SISINNO 2000).

Os resíduos sólidos urbanos, quando dispostos em lixões, causam grande dano estético e na paisagem, pois muitas vezes surgem em áreas que vão sendo aterradas onde antes existia vegetação como a mata atlântica, cerrado, etc... ou surgem simplesmente em becos, vielas, ruas, praças públicas ou terrenos baldios das cidades, causando assim poluição visual, que afeta não só a paisagem como o bem-estar das populações que habitam nas proximidades das áreas de disposição de resíduos sólidos.

Não é a toa que a Lei de PNRS contém proibições expressas quanto às formas de destinação ou disposição final de resíduos sólidos ou rejeitos, justamente visando prevenir danos ambientais, sendo terminantemente proibido o lançamento em praias, no mar ou em quaisquer 
corpos hídricos; lançamento in natura a céu aberto, excetuados os resíduos de mineração; queima a céu aberto ${ }^{6}$ ou em recipientes, instalações e equipamentos não licenciados para essa finalidade; e outras formas vedadas pelo poder público. Igualmente a lei proíbe também, nas áreas de disposição final de resíduos ou rejeitos, as seguintes atividades: utilização dos rejeitos dispostos como alimentação; catação, observado o disposto no inciso V do art. 17; criação de animais domésticos; fixação de habitações temporárias ou permanentes; outras atividades vedadas pelo poder público (artigos 47 e 48).

Por fim, no aspecto social, uma correta e eficiente gestão dos RSU trazem inegáveis benefícios sociais, na medida em que pessoas de baixa renda e que vivem da reciclagem de resíduos, através de Cooperativas ou associações de catadores, podem ter acesso à geração de renda e cidadania. Um dos objetivos da PNRS é a integração dos catadores de materiais reutilizáveis e recicláveis nas ações que envolvam a responsabilidade compartilhada pelo ciclo de vida dos produtos, e um dos instrumentos é o incentivo à criação e ao desenvolvimento de cooperativas ou de outras formas de associação de catadores de materiais reutilizáveis e recicláveis.

O Decreto Federal 7.404/2010 dedicou o Título V - artigos 40 a 44 descrevendo a participação dos catadores de materiais recicláveis e reutilizáveis, apontando que os sistemas de coleta seletiva de resíduos sólidos e a logística reversa deverão priorizar a participação de cooperativas ou de outras formas de associação de catadores.

\section{OS ENTES PÚBLICOS E SUAS OBRIGAÇÕES LEGAIS PARA O CUMPRIMENTO E SUCESSO NA IMPLANTAÇÃO DA PNRS}

O sucesso na implantação da PNRS depende da participação e cumprimento de tarefas pela União, Estados-membros e Municípios. A legislação estabelece o papel de cada ente neste processo.

Cabe à União organizar e manter de forma conjunta o Sistema Nacional de Informações sobre a Gestão dos Resíduos Sólidos (Sinir), articulado com o Sistema Nacional de Informações em Saneamento Básico (Sinisa) e o Sistema Nacional de Informações sobre Meio Ambiente (Sinima). Estão envolvidos nesse processo o Ministério do Meio Ambiente, o Ministério das Cidades - que recebe os PMGIRS elaborados pelos Municípios e define os critérios e prioridades para distribuição de recursos; o Ministério da Saúde - como instituição que possui poderes normativos abarcando os aspectos sanitários relacionados ao manejo dos resíduos sólidos e, por fim, o Ministério da Educação - com incumbência de aplicar os instrumentos da PNRS relativos à educação ambiental. Também é sua obrigação a elaboração do Plano Nacional de Resíduos Sólidos, conforme conteúdo previsto no artigo 15, incisos I a XV da Lei 12.305/10, de modo a trazer um diagnóstico, a partir de dados secundários, da atual situação dos resíduos sólidos no país, identificando cenários, estabelecendo metas, diretrizes e estratégias para implantação da PNRS.

Já os Estados-membros devem promover a organização, o planejamento e a execução das funções públicas de interesses comuns relacionados à gestão de resíduos sólidos nas regiões metropolitanas, aglomerações urbanas e microrregiões, através da obrigatoriedade de elaboração dos Planos Estaduais de Resíduos Sólidos e dos Planos Regionais Metropolitanos ou

6 Salvo exceção prevista no artigo $47, \S 1^{\circ}$ Quando decretada emergência sanitária, a queima de resíduos a céu aberto pode ser realizada, desde que autorizada e acompanhada pelos órgãos competentes do Sisnama, do SNVS e, quando couber, do Suasa. 
microrregionais de resíduos sólidos, cujos conteúdos devem observar o disposto no artigo 17 da Lei 12.305/2010. Além do mais, compete aos Estados-membros controlar e fiscalizar as atividades dos geradores sujeitas a licenciamento ambiental pelo órgão estadual do Sisnama, como ainda apoiar e priorizar as iniciativas do Município de soluções consorciadas ou compartilhadas entre 2 (dois) ou mais Municípios.

Por fim, cabe aos Municípios efetivar a implantação da PNRS, na medida em que são titulares na gestão dos serviços públicos de limpeza urbana e manejo dos resíduos sólidos urbanos, obrigação esta já anteriormente delineada pelo artigo 30, incisos I e V da CF, reforçada pelo artigo 10 da Lei Federal 12.305/2010. Os Municípios também são obrigados a elaborar o Plano Municipal de Gestão Integrada de Resíduos Sólidos com o conteúdo mínimo previsto no artigo 19. Por fim, como titular dos serviços públicos de limpeza urbana e de manejo de resíduos sólidos, é responsável pela organização e prestação direta ou indireta desses serviços, observados o respectivo plano municipal de gestão integrada de resíduos sólidos, a Lei $\mathrm{n}^{\circ}$ 11.445, de 2007, e as disposições desta Lei e seu regulamento (artigo 16). Como se sabe, os resíduos são classificados pelo artigo 13, quanto à origem em: a) resíduos domiciliares: os originários de atividades domésticas em residências urbanas; b) resíduos de limpeza urbana: os originários da varrição, limpeza de logradouros e vias públicas e outros serviços de limpeza urbana, sendo que ambos compõem o que se denomina resíduos sólidos urbanos (RSU). Estes resíduos são de inteira responsabilidade do Município quanto a sua correta gestão e gerenciamento.

\title{
3 DA Logística ReVERSA.
}

\subsection{Conceito. Princípios. Produtos e embalagens sujeitos ao sistema. Vantagens.}

Dentre os vários instrumentos previstos no artigo $8^{\circ}$ da Lei Federal 12.305/2010 para a implantação da PNRS temos a Logística Reversa conceituada como um "instrumento de desenvolvimento econômico e social caracterizado pelo conjunto de ações, procedimentos e meios destinados a viabilizar a coleta e a restituição dos resíduos sólidos ao setor empresarial, para reaproveitamento, em seu ciclo ou em outros ciclos produtivos, ou outra destinação final ambientalmente adequada". ${ }^{7}$

Comentando sobre a Logística Reversa, Milaré (2013, p. 1176) destacou em sua obra que:

\begin{abstract}
A logística reversa constitui uma das ferramentas relacionadas à implementação da responsabilidade compartilhada pelo ciclo de vida dos produtos. $\mathrm{O}$ aludido instrumento tem como fundamento básico o princípio do poluidor-pagador, na medida em que exige a internalização dos custos provenientes da destinação e disposição final dos resíduos sólidos gerados por determinados produtos e embalagens.
\end{abstract}

O princípio do poluidor-pagador, reconhecido como um dos mais importantes na tutela do meio ambiente, postula que o causador da poluição arcará com seus custos, ou seja, responderá pelas despesas de prevenção, reparação e repressão da poluição.

7 Lei $12.305 / 2010$, art. $3^{\circ}$, XII e Decreto 7.404/2010, art.13. 
Logística reversa: qual é o papel dos municípios no cenário da Política Nacional de Resíduos Sólidos?

Comentando sobre o mencionado princípio, Lemos (2014, p. 59-60) destaca em sua obra que:

\begin{abstract}
O princípio do poluidor-pagador visa eliminar do processo produtivo as chamadas externalidades negativas ambientais... estaremos diante de uma externalidade negativa toda vez que parte dos custos decorrentes da produção e do consumo de um bem forem direcionados para indivíduos alheios a esta cadeia de produção e consumo. No caso dos recursos ambientais, podemos afirmar que haverá uma externalidade negativa toda vez que um impacto ambiental gerado pela produção e pelo consumo não for suportado pelos agentes diretamente beneficiados pela atividade produtiva. Isso significa que os custos ambientais estarão sendo transferidos para a coletividade, tendo-se em vista que os bens ambientais são bem de uso comum do povo.
\end{abstract}

Outro princípio em harmonia com o tema Logística Reversa é o da responsabilidade compartilhada pelo ciclo de vida dos produtos definido como "conjunto de atribuições, individualizadas e encadeadas dos fabricantes, importadores, distribuidores e comerciantes, dos consumidores e dos titulares dos serviços públicos de limpeza urbana e de manejo dos resíduos sólidos, para minimizar o volume de resíduos sólidos e rejeitos gerados, bem como para reduzir os impactos causados à saúde humana e à qualidade ambiental decorrentes do ciclo de vida dos produtos, nos termos desta Lei". 8

O tema não é novidade em nossa legislação. Tal sistema já foi previsto e implantado para os agrotóxicos, seus resíduos e embalagens, na forma da Lei 7.802, de 11 de julho de 1989, e no Decreto no 4.074, de 4 de janeiro de 2002.

No ano de 2001 foi criado o INPEV - Instituto Nacional de Processamento de Embalagens Vazias, uma entidade sem fins lucrativos criada pela indústria fabricante de defensivos agrícolas para realizar a gestão pós-consumo das embalagens vazias de seus produtos, congregando um rol de mais de 100 empresas e nove entidades representativas da indústria, dos canais de distribuição e dos agricultores, sendo que em 2002 foi implantado o programa "Campo Limpo". Segundo dados divulgados pela ABRELPE sobre o "Panorama dos resíduos sólidos em 2014 no Brasil", o país tem destinação correta superior a países como a Alemanha (76\%), Canadá (73\%); França (66\%); Japão (50\%) e EUA (33\%).

\footnotetext{
Atualmente, cerca de $94 \%$ das embalagens plásticas primárias, que entram em contato direto com o produto, e cerca de $80 \%$ do total de embalagens vazias de defensivos agrícolas que são comercializadas, têm destino adequado. Em 2014, foram destinadas de forma ambientalmente correta 42.645 toneladas de embalagens vazias de defensivos agrícolas em todo o país. Comparado a 2013, a logística do material alcançou um crescimento de 6\%. Esses índices transformaram o Brasil em líder e referência mundial no assunto....
}

Com relação a pilhas, baterias e pneus, a logística reversa também foi implantada anteriormente a Lei de PNRS através das Resoluções CONAMA 257/1999 e 258/1999 atualmente revogadas pelas Resoluções CONAMA 401/2008 e 416/2009.

Com o advento da Lei Federal 12.305/2010, o legislador ratificou a obrigatoriedade da Logística Reversa em relação aos produtos acima indicados e ampliou para outros, apontando no artigo 33 os seguintes produtos e embalagens sujeitos ao sistema: 1 - agrotóxicos, seus resíduos e embalagens, assim como outros produtos cuja embalagem, após o uso, constitua resíduo perigoso, observadas as regras de gerenciamento de resíduos perigosos previstas em lei ou regulamento, em normas estabelecidas pelos órgãos do Sisnama, do SNVS e do Suasa, ou em normas técnicas; 2 - pilhas e baterias; 3 - pneus; 4 - óleos lubrificantes, seus resíduos e embala-

8 Lei $12.305 / 2010$, art. $3^{\circ}$, XVII. 
gens; 5 - lâmpadas fluorescentes, de vapor de sódio e mercúrio e de luz mista; 6 - produtos eletroeletrônicos e seus componentes. ${ }^{9}$

O rol dos produtos e embalagens é meramente exemplificativo, já que os sistemas de Logística Reversa poderão ser estendidos a produtos comercializados em embalagens plásticas, metálicas ou de vidro e aos demais produtos e embalagens, considerando, prioritariamente, a viabilidade técnica e econômica da Logística Reversa, bem como o grau e a extensão do impacto à saúde pública e ao meio ambiente dos resíduos gerados. ${ }^{10}$ Neste caso, a definição dos produtos e embalagens deverá considerar a viabilidade técnica e econômica da Logística Reversa, a ser definido pelo Comitê Orientador, órgão criado pelo Decreto Federal 7.404/2010 para a implementação de sistemas de Logística Reversa. ${ }^{11}$

Um exemplo de sucesso na implantação da Logística Reversa no Brasil é a reciclagem de alumínio. Conforme dados divulgados pela Associação Brasileira do Alumínio, o Brasil lidera o ranking mundial de índice de reciclagem de latas de alumínio desde 2001 e, no ano de 2014, movimentou cerca de R \$ 1,7 bilhão e gerou emprego e renda para quase 170 mil pessoas, comprovando essa atividade de reciclagem de latas sua importância socioeconômica.

A reciclagem do alumínio traz benefícios sociais, econômicos e ao meio ambiente, conforme destacado pela Associação Brasileira de Alumínio:

\begin{abstract}
Além dos benefícios sociais e econômicos, a reciclagem de latas de alumínio também favorece o meio ambiente. O processo de reciclagem de latinhas libera somente $5 \%$ das emissões de gás de efeito estufa quando comparado com a produção de alumínio primário. Ao substituir um volume equivalente de alumínio primário, a reciclagem de 139,1 mil toneladas de latinhas proporcionou uma economia de $1.976 \mathrm{GWh} /$ ano de energia elétrica ao País, o suficiente para abastecer, por um ano inteiro, uma cidade com mais de um milhão de habitantes, como Campinas (SP). Além disso, poupou 700 mil toneladas de bauxita (minério do qual se obtém o alumínio), que seriam extraídas das reservas naturais brasileiras. ${ }^{12}$
\end{abstract}

Reforçando as informações dos dados divulgados pela ABRELPE (2015, p. 106), “O Brasil vem mantendo a liderança mundial nesse segmento específico, tendo atingido, em 2012, o índice de $97,9 \%$, que corresponde a 260 mil toneladas recicladas".

\title{
3.2 Responsabilidade compartilhada pelo ciclo de vida dos produtos.
}

A responsabilidade compartilhada pelo ciclo de vida dos produtos, ou também conhecida como responsabilidade pós-consumo, está disciplinada nos artigos 30 a 36 da Lei Federal 12.305/2010 e é definida como o "conjunto de atribuições individualizadas e encadeadas dos fabricantes, importadores, distribuidores e comerciantes, dos consumidores e dos titulares dos serviços públicos de limpeza urbana e de manejo dos resíduos sólidos, para minimizar o volume dos resíduos sólidos e rejeitos gerados, bem como reduzir os impactos causados à saúde humana e à qualidade ambiental decorrentes do ciclo de vida dos produtos". ${ }^{13}$

Dentre os objetivos da responsabilidade pós-consumo podemos destacar, dentre outros: a) o aproveitamento dos resíduos sólidos na cadeia produtiva; b) redução da geração de resíduos e do desperdício de materiais, da poluição e dos danos ambientais; c) o estímulo ao de-

9 Lei 12.305/2010, art. 33 "caput”, incisos I a VI.

${ }^{10}$ Lei $12.305 / 2010$, art. $33, \S \S 1^{\circ}$ e $2^{\circ}$.

11 Decreto 7.404/2010, art.17, parágrafo único e art. 33.

$12 \mathrm{http} / / /$ www.abal.org.br/noticias/lista-noticia/integra-noticia/?id=359. Acesso em: 03 jul. 2015.

${ }^{13}$ Lei $12.305 / 2010$, art.3 $3^{\circ}$ XVII. 
senvolvimento de mercado, da produção e do consumo de produtos derivados de materiais reciclados e recicláveis. ${ }^{14}$

Aos fabricantes, importadores, distribuidores e comerciantes a PNRS imputou responsabilidades que abrangem: a) investimentos no desenvolvimento, na fabricação e na colocação no mercado de produtos que sejam aptos, após o uso pelo consumidor, à reutilização, à reciclagem ou a outra forma de destinação ambientalmente adequada; b) divulgação de informações relativas às formas de evitar, reciclar e eliminar os resíduos associados a seus respectivos produtos; c) compromisso de, quando firmados acordos setoriais e termos de compromissos com o Município, participar das ações previstas no plano municipal de gestão integrada de resíduos sólidos, no caso de produtos ainda não inclusos no sistema de logística reversa; d) recolhimento dos produtos e dos resíduos remanescentes após o uso, assim como sua subsequente destinação final ambientalmente adequada, no caso de produtos objetos de sistema de logística reversa na forma do artigo 33, ou seja, estruturação e implantação da Logística Reversa. ${ }^{15}$

Comentando sobre o tema, Lemos (2014, p. 108) em sua obra enfatizou que:

\begin{abstract}
Não há dúvida que, mesmo no caso de materiais não reutilizáveis ou não recicláveis, persiste a responsabilidade da cadeia produtiva dos produtos sujeitos à logística reversa. Tanto é assim que os rejeitos devem ser encaminhados pelos fabricantes e importadores para a disposição final ambientalmente adequada, na forma estabelecida pelo órgão competente do Sisnama e, se houver, pelo plano municipal de gestão integrada de resíduos sólidos.
\end{abstract}

Ainda, todo aquele que manufatura embalagens ou fornece materiais para a fabricação de embalagens, ou coloca em circulação embalagens, materiais para fabricação de embalagens ou produtos embalados, em qualquer fase da cadeia de comércio, são também responsáveis pela fabricação de embalagens com materiais que propiciem a reutilização ou a reciclagem, cabendo aos responsáveis assegurar que as embalagens sejam: a) restritas em volume e peso às dimensões requeridas à proteção do conteúdo e à comercialização do produto; b) projetadas de forma a serem reutilizadas de maneira tecnicamente viável e compatível com as exigências aplicáveis ao produto que contém e, c) recicladas, se a reutilização não for possível. ${ }^{16}$

Ao comentar sobre estas obrigações previstas para o setor empresarial, Lemos (2014, p. 108) consignou em sua obra que:

No caso dos resíduos sujeitos à logística reversa no âmbito da legislação brasileira, há diversas obrigações para a cadeia produtiva (fabricantes, importadores, distribuidores e comerciantes) como a divulgação de informações relativas a como evitar, reciclar e eliminar resíduos associados aos seus produtos, bem como o recolhimento dos produtos e dos resíduos remanescentes após o uso e, ainda, a obrigação de dar destinação final ambientalmente adequada. Neste caso, a cadeia produtiva apontada fica obrigada a estruturar e implementar sistemas de logística reversa, de forma que o retorno dos produtos pós-consumo se dê de forma independente do serviço público de limpeza urbana e de manejo dos resíduos sólidos.

Na responsabilidade compartilhada pelo ciclo de vida dos produtos, não podemos nos esquecer das obrigações expressas aos consumidores, que deverão efetuar a devolução dos produtos ou embalagens aos comerciantes ou distribuidores. ${ }^{17}$ Estes, por sua vez, deverão efetuar a devolução aos fabricantes e importadores dos produtos reunidos ou devolvidos. Finalizando, os fabricantes e os importadores darão destinação ambientalmente adequada aos produtos e às embalagens reunidos ou devolvidos, sendo o rejeito encaminhado para disposição final

\footnotetext{
${ }^{14}$ Lei 12.305/2010, art.30, parágrafo único, incisos I a VII.

15 Lei $12.305 / 2010$, art.31.

${ }^{16}$ Lei $12.305 / 2010$, art.32.

${ }^{17}$ Lei $12.305 / 2010$, art.28 e $33, \S 4^{\circ}$.
} 
ambientalmente adequada, na forma estabelecida pelo órgão competente do Sisnama e, se houver, pelo plano municipal de gestão integrada de resíduos sólidos. ${ }^{18}$

Com relação ao titular do serviço público de limpeza urbana e de manejo de resíduos, não cabe assumir qualquer responsabilidade pela logística reversa. Poderá, entretanto, fazê-lo mediante acordo setorial ou termo de compromisso firmado com o setor empresarial, encarregando-se do recolhimento dos produtos e das embalagens após o uso. Para tanto, as ações do poder público serão devidamente remuneradas, na forma previamente acordada pelas partes. ${ }^{19}$

\subsection{O Comitê Orientador}

Para a implementação de sistemas de Logística Reversa, a legislação federal criou o Comitê Orientador, composto pelo Ministro de Estado do Meio Ambiente, Ministro de Estado da Saúde, Ministro de Estado do Desenvolvimento, Indústria e Comércio Exterior, Ministro de Estado da Agricultura, Pecuária e Abastecimento e pelo Ministro de Estado da Fazenda. ${ }^{20}$

É presidido pelo Ministro de Estado do Meio Ambiente e o Ministério do Meio Ambiente exerce a função de secretaria-executiva, incumbida de expedir os atos decorrentes das decisões do colegiado. O Comitê Orientador será assessorado por grupo técnico, composto por representantes do Ministério do Meio Ambiente, do Ministério da Saúde, do Ministério do Desenvolvimento, Indústria e Comércio Exterior, do Ministério da Fazenda e do Ministério de Agricultura, Pecuária e Abastecimento. Este grupo técnico poderá ser composto por representantes de outros Ministérios, de órgãos e entidades da administração pública federal; dos Estados, do Distrito Federal e dos Municípios; e de entidades representativas de setores da sociedade civil diretamente impactados pela logística reversa, sempre que forem abordados temas referentes às suas respectivas competências ou áreas de atuação. ${ }^{21}$

As decisões do Comitê Orientador serão tomadas por maioria simples de votos, presente a maioria absoluta dos membros. Seu regimento interno deve conter, no mínimo: 1 - o procedimento para divulgação da pauta das reuniões; 2 - os critérios para participação dos órgãos e entidades no grupo técnico; 3 - as regras para o funcionamento do grupo técnico de assessoramento e do colegiado; e 4 - os critérios de decisão no caso de empate nas deliberações colegiadas. $^{22}$

Compete ao Comitê Orientado, dentre as várias atribuições previstas ${ }^{23}$, estabelecer a orientação estratégica da implementação de sistemas de Logística Reversa instituídos nos termos da Lei n 12.305, de 2010, e do Decreto Federal 7.404/2010.

${ }^{18}$ Lei $12.305 / 2010$, art.33, $\S 5^{\circ}$ e $6^{\circ}$.

${ }^{19}$ Lei $12.305 / 2010$, art.33, $\S 7^{\circ}$.

${ }^{20}$ Decreto $7.404 / 2010$, art.33

${ }^{21}$ Decreto $7.404 / 2010$, art.33, $\S \S 1^{\circ}, 2^{\circ}, 3^{\circ}$ e $4^{\circ}$.

22 Decreto $7.404 / 2010$, art.33, $\S \S 6^{\circ}$ e $7^{\circ}$.

${ }^{23}$ Decreto 7.404/2010, art.34. 


\subsection{Instrumentos para a implantação e operacionalização da logística}

\section{reversa.}

Para a implantação da logística reversa, a PNRS previu os seguintes instrumentos: 1) acordos setoriais; 2) regulamentos expedidos pelo Poder Público; 3 ) termos de compromisso. ${ }^{24}$

$\mathrm{O}$ acordo setorial é indicado como um dos instrumentos da PNRS ${ }^{25}$ e definido como "ato de natureza contratual firmado entre o poder público e fabricantes, importadores, distribuidores ou comerciantes, tendo em vista a implantação da responsabilidade compartilhada pelo ciclo de vida do produto". ${ }^{26}$

O procedimento para implantação da Logística Reversa por meio de acordos setoriais poderá ser iniciado pelo Poder Público ou pelos fabricantes, importadores, distribuidores ou comerciantes. ${ }^{27}$

Quando iniciados pelo Poder Público, os acordos setoriais serão precedidos de editais de chamamento. ${ }^{28}$ No caso dos procedimentos de iniciativa da União, a publicação de editais de chamamento pelo Ministério do Meio Ambiente poderão indicar: 1 - os produtos e embalagens que serão objeto da Logística Reversa, bem como as etapas do ciclo de vida dos produtos e embalagens que estarão inseridas na referida logística; 2 - o chamamento dos interessados, conforme as especificidades dos produtos e embalagens referidos no item 1; 3 - o prazo para que o setor empresarial apresente proposta de acordo setorial, observados os requisitos mínimos estabelecidos no Decreto 7.404/2010 e no edital; 4 - as diretrizes metodológicas para avaliação dos impactos sociais e econômicos da implantação da Logística Reversa; 5 - a abrangência territorial do acordo setorial; e 5 - outros requisitos que devam ser atendidos pela proposta de acordo setorial, conforme as especificidades dos produtos ou embalagens objeto da logística reversa. ${ }^{29}$

A publicação do edital de chamamento será precedida da aprovação pelo Comitê Orientador, da avaliação da viabilidade técnica e econômica da implantação da logística reversa, promovida pelo grupo técnico previsto no $\S 3^{\circ}$ do art. 33, cujas diretrizes metodológicas para tal avaliação serão estabelecidas pelo Comitê Orientador. ${ }^{30}$

Quando iniciados pelos fabricantes, importadores, distribuidores ou comerciantes serão precedidos da apresentação de proposta formal pelos interessados ao Ministério de Meio Ambiente $^{31}$, contendo os seguintes requisitos: 1 - indicação dos produtos e embalagens objeto do acordo setorial; 2 - descrição das etapas do ciclo de vida em que o sistema de logística reversa se insere, observado o disposto no inciso IV do art. $3^{\circ}$ da Lei $n^{\circ} 12.305$, de 2010; 3 - descrição da forma de operacionalização da logística reversa; 4 - possibilidade de contratação de entidades, cooperativas ou outras formas de associação de catadores de materiais recicláveis ou reutilizáveis para execução das ações propostas no sistema a ser implantado; 5 - participação de órgãos públicos nas ações propostas, quando estes se encarregarem de alguma etapa da logística a ser implantada; 6 - definição das formas de participação do consumidor; 7 - mecanismos para a divulgação de informações relativas aos métodos existentes para evitar, reciclar e elimi-

${ }^{24}$ Lei 12.305/2010, art.33, § $3^{\circ}$, I, II e III e Decreto 7.404/2010, art.15.

${ }^{25}$ Lei $12.305 / 2010$, art. $8^{\circ}$, XVI.

${ }^{26}$ Lei $12.305 / 2010$, art. $3^{\circ}$, I.

${ }^{27}$ Decreto 7.404/2010, art.20 "caput".

${ }^{28}$ Decreto $7.404 / 2010$, art. 20, $\$ 1^{\circ}$.

${ }^{29}$ Decreto 7.404/2010, art.21, incisos I a V.

${ }^{30}$ Decreto $7.404 / 20101$, art. $21, \S \S 1^{\circ}$ e $2^{\circ}$.

${ }^{31}$ Decreto 7.404/2010, art. 20, § $2^{\circ}$. 
nar os resíduos sólidos associados a seus respectivos produtos e embalagens; 8 - metas a serem alcançadas no âmbito do sistema de logística reversa a ser implantado, fixadas com base em critérios quantitativos, qualitativos ou regionais; 9 - cronograma para a implantação da logística reversa, contendo a previsão de evolução até o cumprimento da meta final estabelecida; 10 informações sobre a possibilidade ou a viabilidade de aproveitamento dos resíduos gerados, alertando para os riscos decorrentes do seu manuseio; 11 - identificação dos resíduos perigosos presentes nas várias ações propostas e os cuidados e procedimentos previstos para minimizar ou eliminar seus riscos e impactos à saúde humana e ao meio ambiente; 12 - avaliação dos impactos sociais e econômicos da implantação da logística reversa; 13 - descrições do conjunto de atribuições individualizadas e encadeadas dos participantes do sistema de logística reversa no processo de recolhimento, armazenamento, transporte dos resíduos e embalagens vazias, com vistas à reutilização, reciclagem ou disposição final ambientalmente adequada, contendo o fluxo reverso de resíduos, a discriminação das várias etapas da logística reversa e a destinação dos resíduos gerados, das embalagens usadas ou pós-consumo e, quando for o caso, das sobras do produto, devendo incluir: a) recomendações técnicas a serem observadas em cada etapa da logística, inclusive pelos consumidores e recicladores; b) formas de coleta ou de entrega adotadas, identificando os responsáveis e respectivas responsabilidades; c) ações necessárias e critérios para a implantação, operação e atribuição de responsabilidades pelos pontos de coleta; d) operações de transporte entre os empreendimentos ou atividades participantes, identificando as responsabilidades; e e) procedimentos e responsáveis pelas ações de reutilização, de reciclagem e de tratamento, inclusive triagem dos resíduos, bem como pela disposição final ambientalmente adequada dos rejeitos; e 14 - cláusulas prevendo as penalidades aplicáveis no caso de descumprimento das obrigações previstas no acordo. ${ }^{32}$

As propostas apresentadas, além dos requisitos acima elencados, deverão estar acompanhadas dos seguintes documentos: 1 - atos constitutivos das entidades participantes e relação dos associados de cada entidade, se for o caso; 2 - documentos comprobatórios da qualificação dos representantes e signatários da proposta, bem como cópia dos respectivos mandatos; e 3 cópia de estudos, dados e demais informações que embasarem a proposta. ${ }^{33}$

As propostas apresentadas, na forma definida pelo Comitê Orientador, serão submetidas à consulta pública ${ }^{34}$ e o Ministério do Meio Ambiente deverá, por ocasião da realização da consulta pública: 1 - receber e analisar as contribuições e documentos apresentados pelos órgãos e entidades públicas e privadas; e 2 - sistematizar as contribuições recebidas, assegurando-lhes a máxima publicidade. ${ }^{35}$

Após, o Ministério do Meio Ambiente fará a avaliação das propostas de acordo setorial apresentadas consoante os seguintes critérios mínimos: 1 - adequação da proposta à legislação e às normas aplicáveis; 2 - atendimento ao edital de chamamento, no caso dos processos iniciados pelo Poder Público, e apresentação dos documentos que devem acompanhar a proposta, em qualquer caso; 3 - contribuição da proposta e das metas apresentadas para a melhoria da gestão integrada e do gerenciamento ambientalmente adequado dos resíduos sólidos e para a redução dos impactos à saúde humana e ao meio ambiente; 4 - observância do disposto no art. $9^{\circ}$ da Lei $\mathrm{n}^{\circ}$ 12.305, de 2010, quanto à ordem de prioridade da aplicação da gestão e gerenciamento de resíduos sólidos propostos; 5 - representatividade das entidades signatárias em relação à participação de seus membros no mercado dos produtos e embalagens envolvidos; e 6 - contribuição das ações propostas para a inclusão social e geração de emprego e renda dos integrantes de

\footnotetext{
${ }^{32}$ Decreto 7.404/2010, art.23.

33 Decreto 7.404/2010, art.25.

${ }^{34}$ Decreto $7.404 / 2010$, artigo 26.

35 Decreto 7.404/2010, art.27.
} 
cooperativas e associações de catadores de materiais reutilizáveis e recicláveis constituídas por pessoas físicas de baixa renda. ${ }^{36}$

Concluída a avaliação, o Ministério do Meio Ambiente enviará a proposta ao Comitê Orientador, que poderá: 1 - aceitar a proposta, hipótese em que convidará os representantes do setor empresarial para assinatura do acordo setorial; 2 - solicitar aos representantes do setor empresarial a complementação da proposta de estabelecimento de acordo setorial; ou 3 - determinar o arquivamento do processo, quando não houver consenso na negociação do acordo. ${ }^{37}$

Uma vez finalizado o acordo setorial contendo a Logística Reversa pactuada, será o mesmo subscrito pelos representantes do setor empresarial e pelo Presidente do Comitê Orientador, devendo ser publicado no Diário Oficial da União. ${ }^{38}$

Além da participação na elaboração dos acordos setoriais de representantes do Poder Público, dos fabricantes, importadores, comerciantes e distribuidores dos produtos e embalagens referidos no art. 33 da Lei $n^{\circ} 12.305$, de 2010, poderão também participar representantes: 1) das cooperativas ou outras formas de associações de catadores de materiais recicláveis ou reutilizáveis; 2) das indústrias e entidades dedicadas à reutilização, ao tratamento e à reciclagem de resíduos sólidos; 3) das entidades de representação dos consumidores, entre outros. ${ }^{39}$

Outro instrumento previsto para implantação e operacionalização da Logística Reversa é o Regulamento, veiculado por decreto editado pelo Poder Executivo.

Porém, antes da edição do regulamento, o Comitê Orientador deverá avaliar a viabilidade técnica e econômica da logística reversa na forma já explicitada acima, bem como os sistemas de Logística Reversa estabelecidos diretamente pelo decreto deverão ser precedidos de consulta pública, cujo procedimento será estabelecido pelo Comitê Orientador. ${ }^{40}$

Por fim, o outro instrumento da $\mathrm{PNRS}^{41}$ é o termo de compromisso, que também se trata de um instrumento celebrado entre o Poder Público e os fabricantes, importadores, distribuidores ou comerciantes, visando o estabelecimento de sistema de Logística Reversa.

Entretanto, este instrumento está previsto para ser utilizado: 1 - nas hipóteses em que não houver, em uma mesma área de abrangência, acordo setorial ou regulamento específico; 2 para a fixação de compromissos e metas mais exigentes que o previsto em acordo setorial ou regulamento. ${ }^{42}$

Os termos de compromisso terão eficácia a partir de sua homologação pelo órgão ambiental competente do SISNAMA, conforme sua abrangência territorial. ${ }^{43}$

\subsection{Disposições comuns aos instrumentos do sistema e abrangência.}

A PNRS estabelece algumas disposições comuns aos instrumentos acima indicados. A primeira delas é que a lei "estabelece um limite na responsabilidade dos fabricantes, importadores, distribuidores e comerciantes, ou seja, eles ficam responsáveis no limite da proporção

\footnotetext{
36 Decreto 7.404/2010, art.28.

37 Decreto 7.404/2010, art.29.

38 Decreto 7.404/2010, art.29, parágrafo único.

${ }^{39}$ Decreto 7.404/2010, art.20, § $3^{\circ}$.

${ }^{40}$ Decreto 7.404/2010, art.30 e 31.

${ }^{41}$ Lei $12.305 / 2010$, art. $8^{\circ}$, XVIII.

42 Decreto 7.404/2010, art.32, incisos I e II.

${ }^{43}$ Decreto 7.404/2010, art.32, parágrafo único.
} 
dos produtos que colocarem no mercado interno, conforme metas progressivas, intermediárias e finais, estabelecidas no instrumento que determinar a implementação da logística reversa" ${ }^{44}$

A segunda é que os acordos setoriais, assim como os regulamentos e os termos de compromisso que disciplinam a Logística Reversa no âmbito federal, deverão ser avaliados pelo Comitê Orientador em até cinco anos contados da sua entrada em vigor para fins de verificação da necessidade de suas revisões. ${ }^{45}$

Em relação aos acordos setoriais ou termos de compromissos que disciplinam os produtos e embalagens previstas no art. 33 e dos produtos comercializados em embalagens plásticas, metálicas ou de vidro, podem ter abrangência nacional, estadual ou municipal. Os que forem firmados no âmbito nacional têm prevalência sobre os firmados em âmbito regional ou estadual, e estes sobre os firmados em âmbito municipal. Na aplicação das regras concorrentes, os acordos firmados com menor abrangência geográfica podem ampliar, mas não abrandar, as medidas de proteção ambiental constantes nos acordos setoriais e termos de compromissos firmados com maior abrangência geográfica. ${ }^{46}$

Os sistemas de logística reversa dos produtos e embalagens previstos no art. 33, incisos I a IV, da Lei $\mathrm{n}^{\mathbf{0}}$ 12.305, de 2010, cujas medidas de proteção ambiental podem ser ampliadas, mas não abrandadas, deverão observar as exigências específicas previstas em: I - lei ou regulamento; II - normas estabelecidas pelos órgãos do Sistema Nacional do Meio Ambiente SISNAMA, do Sistema Nacional de Vigilância Sanitária - SNVS, do Sistema Único de Atenção à Sanidade Agropecuária - SUASA e em outras normas aplicáveis; ou III - acordos setoriais e termos de compromisso. ${ }^{47}$

\title{
3.6 Procedimentos para operacionalização do sistema da logística reversa.
}

A cadeia produtiva tem a liberdade de operacionalizar o sistema de logística reversa, utilizando-se dos seguintes procedimentos: 1) implantação de procedimentos de compra de produtos ou embalagens usadas; 2) disponibilização de postos de entrega de resíduos reutilizáveis e recicláveis; 3 ) atuação em parceria com cooperativas ou outras formas de associações de catadores de materiais recicláveis ou reutilizáveis.

Trata-se, pois, de um rol exemplificativo, porém, qualquer outro procedimento proposto deve respeitar os princípios da tutela do meio ambiente ecologicamente equilibrado.

Como se pode concluir, a legislação criou os mecanismos necessários à operacionalização da Logística Reversa e conforme ressaltou Milaré (2013, p. 1180) em sua obra,

\begin{abstract}
Os sistemas de logística reversa estão na pauta do dia dos órgãos ambientais do País e tem mobilizado sensivelmente o Poder Legislativo dos Estados e Municípios para sua efetiva regulamentação e implementação, tendo em vista a complexidade do assunto no aspecto material e a sua repercussão no aspecto operacional, tanto para o setor público, como para o setor empresarial e os consumidores, que terão de se acostumar a devolver os produtos e embalagens quando estes se tornem inservíveis.
\end{abstract}

\footnotetext{
44 Decreto 7.404/2010, art.18, § $2^{\circ}$.

45 Decreto 7.404/2010, art.15, § $2^{\circ}$.

${ }^{46}$ Lei $12.305 / 2010$, art.34.

${ }^{47}$ Decreto 7.404/2010, art.16.
} 


\subsection{Os acordos setoriais e os termos de compromissos firmados com o setor empresarial.}

O Governo Federal instalou, no dia 17 de fevereiro de 2011, o Comitê Orientador para acompanhamento da Política Nacional de Resíduos Sólidos, baixando também a Portaria $\mathrm{n}^{\circ} 113$, de 8 de abril de 2011, aprovando o seu Regimento Interno. ${ }^{48}$ Sobre sua composição e atribuições já explicamos no item 4.3 acima.

Com a finalidade de apoiar a estruturação e implementação da PNRS, por meio da articulação dos órgãos e entidades governamentais, de modo a possibilitar o cumprimento das determinações e metas previstas na referida lei, o Comitê Interministerial também criou cinco Grupos Técnicos Temáticos que passaram a discutir Logística Reversa para cinco cadeias prioritárias: descarte de medicamentos; embalagens em geral; embalagens de óleos lubrificantes e seus resíduos; lâmpadas fluorescentes, de vapor de sódio e mercúrio e de luz mista, e eletroeletrônicos, sendo finalizados os trabalhos de duas cadeias prioritárias, através das assinaturas de três acordos setoriais.

O primeiro deles, entre a União, o Sindicato Nacional das Empresas Distribuidoras de Combustíveis e de Lubrificantes - SINDICOM e outras cinco entidades representativas do setor para a implantação do Sistema de Logística Reversa de Embalagens Plásticas de Óleo Lubrificante foi assinado no dia 19/12/2013 e teve seu extrato publicado no D.O. U de 07/02/ $2013 .{ }^{49}$

O segundo acordo setorial entre a União, a Associação Brasileira de Importadores de Produtos de Iluminação - ABILUMI e outras duas entidades representativas do setor para implantação do Sistema de Logística Reversa de Lâmpadas Fluorescentes de Vapor de Sódio e Mercúrio e de Luz Mista foi assinado no dia 27/11/2014 e teve seu extrato publicado no D.O. U de $12 / 03 / 2015 .^{50}$

O terceiro acordo setorial assinado pela União e mais 20 entidades ligadas ao setor da indústria de embalagens em geral é o relativo à implantação da Logística Reversa de Embalagens que foi assinado em 25/11/2015 e publicado no D.O. U de 27/11/2015 $5^{51}$. O setor de embalagens representa um dos maiores geradores, em volume, de resíduos que são dispostos de forma inadequada no país.

Há também outros dois setores envolvendo medicamentos e produtos eletrônicos e seus componentes que se encontram em discussão quanto à lavratura dos respectivos acordos setoriais, sendo que ambos aguardam audiências públicas a serem realizadas, segundo dados divulgados pelo Ministério do Meio Ambiente. ${ }^{52}$

No Estado de São Paulo, através da Lei Estadual n 12.300, de 16 de março de 2006, Decreto Estadual $n^{\circ}$ 54.645, de 5 de agosto de 2009 e antiga Resolução SMA 38/2011, o assunto envolvendo Logística Reversa encontra-se muito mais adiantado.

\footnotetext{
48 http://www.sinir.gov.br/documents/10180/15240/PORTARIA_113/.Acesso em: 03 jul2015.

${ }^{49} \mathrm{http} / / / \mathrm{www}$.sinir.gov.br/web/guest/acordo-setorial-para-implantacao-de-sistema-de-logistica-reversa-deembalagens-plasticas-de-oleo-lubrificante. Acesso em: 30 jun. 2015.


luz-mista. Acesso em: 30 jun. 2015.

${ }^{51} \mathrm{http}: / /$ www.sinir.gov.br/documents/10180/93155/Acordo_embalagens.pdf/58e2cc53-3e38-420a-97fd-dba2ccae4cd3, acesso em 27/07/2017.

${ }^{52} \mathrm{http} / / /$ sinir.gov.br/web/guest/logistica-reversa, acesso em 27.jul.2017.
} 
Para o cumprimento das determinações da Política Estadual de Resíduos Sólidos, a Secretaria do Meio Ambiente e a CETESB, baseadas na edição da promulgação da Resolução SMA no 38/2011 ${ }^{53}$ iniciaram diálogo com o setor empresarial com atuação no Estado de São Paulo. As propostas recebidas no prazo concedido pela Resolução foram analisadas considerando o conteúdo mínimo exigido e a inclusão de um maior número de proponentes, selecionando em cada caso ao menos uma proposta por produto para estabelecimento de Termos de Compromisso. Outras duas Resoluções foram editadas com determinações semelhantes, incluindo na relação inicial as operadoras de telefonia celular (Resolução SMA n ${ }^{\circ} 11 / 2012$ ) e os medicamentos domiciliares, vencidos ou em desuso (Resolução SMA n 115/2013).

Mais recentemente e considerando a experiência adquirida com o acompanhamento dos sistemas de Logística Reversa reconhecidos nos Termos de Compromisso, foi editada a Resolução SMA n ${ }^{\circ} 45 / 2015^{54}$, que revogou as anteriores e definiu novas diretrizes para implementação e operacionalização da Logística Reversa no Estado de São Paulo - incluindo sua consideração na emissão e renovação das licenças de operação, segundo regras a serem oportunamente divulgadas pela CETESB. ${ }^{55}$

Constam divulgados pela Secretaria Estadual do Meio Ambiente onze termos de compromissos firmados com o setor empresarial para os seguintes produtos: a) Aparelhos de Telefonia Móvel Celular e seus respectivos Acessórios; b) Baterias Automotivas inservíveis de Chumbo-ácido; c) Embalagens de Agrotóxicos; d) Embalagens de Produtos de Higiene Pessoal, Perfumaria, Cosméticos, de Limpeza e Afins; e) Embalagens plásticas de óleos lubrificantes; f) Embalagens vazias de saneantes e desinfetantes e desinfetantes de uso profissional; g) filtros usados de óleos lubrificantes automotivos; h) Óleo Comestível (associação); i) pilhas e baterias; j) pneus inservíveis. ${ }^{56}$

Podemos observar dos acordos setoriais e termos de compromissos já firmados que os sistemas de Logística Reversa deverão ser, preferencialmente, implementados por meio de entidade representativa do setor, contemplando conjuntos de empresas, ou por pessoa jurídica criada com o objetivo de gerenciar o respectivo sistema, facilitando muito o diálogo e, posteriormente, a cobrança das cláusulas acordadas em caso de descumprimento de obrigações e metas.

\subsection{A situação dos não signatários de acordos setoriais e termos de compromissos. O Decreto Federal $n^{0}$ 9.177/2017.}

E, como fica a situação das empresas dos setores, cujos produtos ou embalagens de produtos encontram-se relacionados na legislação pertinente e que não sejam signatárias ou aderentes a um acordo ou termos de compromisso?

Ora, continuam obrigadas a implantar e operacionalizar seus próprios sistemas de Logística Reversa em atendimento à legislação, conforme as disposições da Lei 12.305/2010 e

\footnotetext{
53 A Resolução SMA 38/2011 estabeleceu a relação inicial dos produtos que, após o consumo, resultariam em resíduos de significativo impacto ambiental.

${ }^{54}$ http://www.ambiente.sp.gov.br/legislacao/files/2015/06/Resolu\%C3\%A7\%C3\%A3o-SMA-045-2015-Processo9908-2011-Define-as-diretrizes-para-implementa\%C3\%A7\%C3\%A3o-e-operacionaliza\%C3\%A7\%C3\%A3o-daresponsabilidade-p\%C3\%B3s-consumo-22-6-2015.pdf. Acesso em: 02 jul. 2015.

55 Resolução SMA 45/2015.

${ }^{56} \mathrm{http} / / /$ residuossolidos.cetesb.sp.gov.br/residuos-solidos/responsabilidade-pos-consumo/termos-de-compromisso/. Acesso em: 27 jul. 2017.
} 
Decreto Federal 7.404/2010, ficando, igualmente sujeitas as sanções previstas em lei e que serão tratadas em tópico a seguir.

Para que esta regra ficasse bem clara, dando um importante passo neste assunto, a União recentemente editou o Decreto Federal 9.177/2017 que regulamentou o art. 33 da Lei $n^{\circ}$ 12.305/2010 e complementou os arts. 16 e 17 do Decreto Federal $n^{\circ} 7.404 / 2010^{57}$, estabelecendo normas para os nãos signatários dos acordos setoriais já firmados com a União, visando assegurar a isonomia na fiscalização e no cumprimento das obrigações imputadas aos fabricantes, aos importadores, aos distribuidores e aos comerciantes de produtos, seus resíduos e suas embalagens sujeitos à logística reversa.

Trata-se, pois, de um importante instrumento legal para a implantação da Logística Reversa no País, inclusive, trazendo mais justiça a situação daqueles setores empresariais que atenderam aos chamados públicos e firmaram os acordos vigentes, pois o novel Decreto impõe aos nãos signatários as obrigações de estruturar e implementar a Logística Reversa, impondo também as mesmas obrigações assumidas pelos signatários dos acordos já firmados, referentes as etapas de operacionalização, aos prazos, às metas, aos controles e aos registros da operacionalização dos sistemas de logística reversa, aos planos de comunicação, às avaliações e aos monitoramentos dos sistemas, às penalidades e às obrigações específicas imputáveis aos fabricantes, aos importadores, aos distribuidores e aos comerciantes, sendo que eventuais termos aditivos firmados posteriormente pelos signatários, sujeitarão os não signatários as mesmas obrigações complementares eventualmente pactuadas.

O Decreto reafirma a regra de que a celebração de acordos setoriais ou termos de compromisso em âmbito estadual, distrital ou municipal não altera as obrigações dos fabricantes, dos importadores, dos distribuidores e dos comerciantes não signatários e serão compatíveis com as normas previstas em acordo setorial ou termo de compromisso firmado com a União, conforme o disposto no art. 34, $\S 1$ - , da Lei no 12.305 , de 2010, ressalvadas as hipóteses de aplicação do disposto no $\S 2$ - do art. 34 da referida Lei.

Quanto a aplicação de penalidades previstas na legislação ambiental e que serão tratadas a seguir, o Decreto também deixa claro que o descumprimento das obrigações previstas em acordo setorial ou termo de compromisso, inclusive daquelas decorrentes do disposto no art. 2o ou no art. 3-, aplicam-se aos signatários, aos aderentes e aos não signatários.

Quanto a fiscalização, a mesma caberá aos órgãos executores, seccionais e locais do Sistema Nacional do Meio Ambiente, sem prejuízo da competência de outros órgãos e entidades públicos designados para este fim.

\subsection{Penalidades.}

Importante consignar que o art. 51 da Lei 12.305/2010 prevê que, sem prejuízo da obrigação de reparar os danos causados, independentemente da existência de culpa, a ação ou omissão das pessoas físicas ou jurídicas, que importe a inobservância aos preceitos da Lei 12.305/2010 e Decreto 7.404/2010, sujeita os infratores às sanções previstas em lei, em especial às fixadas na Lei Federal 9.605, de 12 de fevereiro de 1998, que dispõe sobre as sanções penais e administrativas derivadas de condutas e atividades lesivas ao meio ambiente.

Na esfera administrativa podemos lançar mão dos artigos 61 e 62, inciso XII do Decreto Federal 6.514, de 22 de julho de 2008, que dispõe sobre as infrações administrativas ao meio

${ }^{57}$ http://www.planalto.gov.br/ccivil_03/_ato2015-2018/2017/decreto/D9177.htm, acesso em 26 de mar.2018. 
ambiente, bem como os artigos 21 e 22 do Decreto Estadual 54.645/09 que regulamenta dispositivos da Lei ${ }^{\circ} 12.300$ de 2006, que institui a Política Estadual de Resíduos Sólidos no Estado de São Paulo. O procedimento para aplicação de tais penalidades no Estado de São Paulo é o Regulamento da Lei 997, de 31 de maio de 1976, aprovado pelo Decreto $\mathrm{n}^{\circ} 8.468$, de 8 de setembro de 1976.

No mais, a atual Resolução SMA 45/2015 estabelece, no artigo 6, que "A observância ao disposto nesta Resolução é considerada obrigação de relevante interesse ambiental para os efeitos da Lei Federal n 9.605, de 12 de fevereiro de 1998”. Como tal, a inobservância dos regramentos da responsabilidade pós-consumo pode caracterizar crime na medida em que previsto no art. 68 da Lei 9.605/1998 que "Deixar, aquele que tiver o dever legal ou contratual de fazê-lo, de cumprir obrigação de relevante interesse ambiental: Pena - detenção, de um a três anos, e multa. Parágrafo único. Se o crime é culposo, a pena é de três meses a um ano, sem prejuízo da multa".

Arremata o artigo $7^{\circ}$ da Resolução SMA que "O não cumprimento a esta Resolução ensejará a aplicação das penalidades previstas na legislação ambiental, em especial as da Lei Estadual n 9.509 , de 20 de março de 1997; da Lei Estadual n ${ }^{\circ} 12.300$, de 16 de março de 2006; do Decreto Estadual $n^{\circ} 54.645$, de 05 de agosto de 2009, e do Decreto Federal $n^{\circ} 6.514$, de 22 de julho de 2008, alterado pelo Decreto Federal n 7.404, de 23 de dezembro de 2010”.

Por fim, com a edição do Decreto 9.177/2017 também se deixou clara a possibilidade de aplicação de todas as penalidades administrativas e penais aos signatários, aos aderentes e aos não signatários dos acordos setoriais ou termos de compromissos já firmados e vigentes.

\subsection{A Logística Reversa e os Municípios.}

Situação que tem despertado bastante interesse e debate em torno da Logística Reversa é a situação dos Municípios frente à implantação e operacionalização deste instrumento. Como os Municípios podem participar deste processo?

A PNRS estabelece como uma de suas diretrizes que incumbe aos Municípios e Distrito Federal a gestão integrada dos resíduos sólidos gerados nos respectivos territórios, sem prejuízo das competências de controle e fiscalização dos órgãos federais e estaduais do Sisnama, do SNVS e do Suasa, bem como da responsabilidade do gerador pelo gerenciamento de resíduos sólidos, consoante artigos 20 a 24 da Lei 12.305/2010. ${ }^{58}$

Ao tratar das responsabilidades dos geradores e do poder público, a PNRS enfatizou que o titular dos serviços públicos de limpeza urbana e de manejo de resíduos sólidos é responsável pela organização e prestação direta ou indireta desses serviços, observados o respectivo plano municipal de gestão integrada de resíduos sólidos, a lei n. 11.445, de 2007, e as disposições da Lei 12.305/2010 e Decreto Federal 7.404/2010.

Devemos relembrar que, de acordo com a classificação de resíduos sólidos quanto à origem, os resíduos sólidos urbanos são os domiciliares, originários de atividades domésticas em residências urbanas; e os resíduos de limpeza urbana, originários da varrição, limpeza de lo-

\footnotetext{
${ }^{58}$ Lei 12.305/2010, art. 10 .

${ }^{59}$ Lei 12.305/2010, art. 26.
} 
Logística reversa: qual é o papel dos municípios no cenário da Política Nacional de Resíduos Sólidos?

gradouros e vias públicas; ou outros serviços de limpeza urbana, como feiras livres, por exemplo. ${ }^{60}$

Por outro lado, conforme já enfatizado neste artigo, a PNRS estabelece a obrigação dos Municípios de elaborar seus planos municipais de gestão integrada de resíduos sólidos, com conteúdo mínimo previsto no artigo 19 da Lei Federal 12.305/2010, sendo que, dentre eles deverá constar do plano a "descrição das formas e dos limites da participação do poder público local na coleta seletiva e na logística reversa, respeitando o disposto no art. 33 e de outras ações relativas à responsabilidade compartilhada pelo ciclo de vida do produto" ${ }^{61}$

Assim, muito embora seja de responsabilidade dos Municípios e DF a gestão integrada dos resíduos sólidos urbanos e seja também sua obrigação elaborar o PMGRIR, contendo a descrição das formas e dos limites de participação dos Municípios na Logística Reversa, a PNRS, através dos art. 33 e do art.36, inciso IV é clara em excluir qualquer responsabilidade do titular do serviço público de limpeza urbana e de manejo de resíduos sólidos na implantação e operacionalização da Logística Reversa. Aliás, consignou como única exceção que o titular do serviço público de limpeza somente poderá encarregar-se das atividades de responsabilidade do setor empresarial nos sistemas de logística reversa dos produtos e embalagens, por acordo setorial ou termo de compromisso firmado com o setor empresarial, sendo que tais ações serão devidamente remuneradas, na forma previamente acordada entre as partes. ${ }^{62}$

Podemos, portanto, concluir que, sem acordo setorial ou termo de compromisso que preveja remuneração pela prestação de serviços de logística reversa, os Municípios e DF estão proibidos de assumir qualquer responsabilidade pela gestão dos resíduos sólidos provenientes do descarte dos produtos e embalagens listados no artigo 33 da Lei 12.305/2010, salvo a exceção mencionada na lei, quando eles forem devidamente remunerados. Por óbvio, a gestão destes resíduos tem custos que vão onerar os cofres públicos, sendo que a PNRS é clara em mandar esta conta para o setor empresarial, em consonância com os princípios do poluidor-pagador e responsabilidade pelo ciclo de vida dos produtos, podendo até os gestores incorrerem na prática de improbidade administrativa prevista no artigo 11, inciso I, da Lei 8.429/1992, ao praticarem ato visando fim proibido em lei, ou regulamento, ou diverso daquele previsto na regra de competência.

Por outro lado, ao analisarmos o artigo 31, inciso IV da Lei 12.305/201063 e os artigos 13 a 34 do Decreto Federal 7.404/2010, Cap. III - Da Logística Reversa, vamos perceber que os Municípios não só podem como devem participar do processo de implantação da Logística Reversa, como gestores e corresponsáveis pela defesa do meio ambiente.

O que temos percebido, entretanto, na prática é que os Municípios estão assistindo passivos a União e os Estados-membros articularem com o setor empresarial acordos setoriais e termos de compromissos, muitas vezes tímidos, que invariavelmente oneram os Municípios, impondo-lhes encargos de responsabilidade do setor empresarial, sem sequer serem convidados para o diálogo.

${ }^{60}$ Lei 12.305/2010, art. 13, I, alíneas "a", "b" e "c".

${ }^{61}$ Lei 12.305/2010, artigo $19, \mathrm{XV}$.

${ }^{62}$ Lei $12.305 / 2010$, artigo $33, \S 7^{\circ}$

63 Art.31, inciso IV - compromisso de, quando firmados acordos ou termos de compromisso com o Município, participar das ações previstas no plano municipal de gestão integrada de resíduos sólidos, no caso de produtos ainda não inclusos no sistema de logística reversa. 
Como exemplo no âmbito federal, citamos a celeuma em torno da discussão da proposta de acordo setorial de embalagens em geral ${ }^{64}$ entre a União, a Associação Brasileira de Atacadistas e Distribuidores de Produtos Industrializados e outras dezenove entidades representativas do setor de embalagens em geral. A proposta de acordo setorial motivou a Confederação Nacional dos Municípios a protocolar junto ao Ministério do Meio Ambiente, através do Ofício n. 2720/14, de 14/10/2014, manifestação contendo críticas ao sistema proposto, com destaque para o fato de o acordo afetar diretamente os Municípios, conforme as razões mencionadas no documento citado. ${ }^{65}$

Outro exemplo, no âmbito estadual, é o termo de compromisso envolvendo a Logística Reversa de embalagens de higiene pessoal, perfumaria, cosméticos, produtos de limpeza e afins e produtos alimentícios firmado pela Secretaria de Meio Ambiente do Estado de São Paulo, Companhia Ambiental do Estado de São Paulo - CETESB, Associação Brasileira da Indústria de Higiene Pessoal, Perfumaria - Cosméticos - ABIHPEC, Associação Brasileira de Produtos de Limpeza e Afins - ABIPLA e Associação Brasileira das Indústrias de Biscoito, Massas Alimentícias e Pães \& Bolos Industrializados - ABIMAPI para a implantação do Programa "Dê a mão para o futuro". ${ }^{6}$

A descrição do sistema envolve as seguintes etapas: a) o consumidor deve separar as embalagens e entregá-las na coleta seletiva municipal; b) as embalagens coletadas devem ser encaminhadas às Centrais de Triagem participantes do Sistema (convênio entre as entidades e Municípios); c) nas Centrais de Triagem serão segregadas, prensadas, enfardadas e armazenadas para comercialização junto a empresas recicladoras; d) nas empresas recicladoras, os materiais serão processados para matéria prima de novas embalagens ou transformação em outros produtos, retornando à cadeia de produção.

As entidades signatárias obrigaram-se a: a) divulgar sistema entre seus associados obrigatoriedade de tomar as medidas, prazos, metas etc.; b) registrar mensalmente a quantidade de materiais recicláveis comercializados pelas centrais de triagem; c) adquirir máquinas e equipamentos para as centrais de triagem, dependendo da necessidade; d) capacitar os catadores; e) encaminhar à SMA relatórios anuais até 31/3; f) divulgar o sistema para sensibilizar a população; g) manter SMA informada da relação atualizada dos associados.

Verifica-se do termo que o mesmo menciona a necessidade de um convênio entre as entidades e Municípios, sem que este tenha participado previamente das discussões e cláusulas do termo de compromisso. Além do mais, este fixou critérios para a seleção das cidades, dando preferência para as cidades localizadas em Regiões Metropolitanas que estejam bem classificadas no ranking do Município Verde Azul, tenham população entre 100.000 a 399.000 mil habitantes, possuam cooperativas regulares e coleta seletiva implantada pelos Municípios.

Conforme podemos observar, além do termo de compromisso limitar a implantação do sistema de Logística Reversa para cidades que não se enquadram nos critérios acordados (significa dizer que muitos municípios paulistas continuarão fora do sistema), o setor empresarial ainda seleciona Municípios que já possuem estruturada a coleta seletiva, centrais de triagem (que, via de regra, estão localizadas em prédios próprios ou locados pelo Município), cooperativas formadas (que, via de regra, são remuneradas pelos Municípios ou se gratificam com os produtos comercializados da coleta seletiva implantada pelos Municípios). Se analisarmos esta

${ }^{64}$ http://sinir.gov.br/documents/10180/17496/PROPOSTA_ACORDO_SETORIAL_EMBALAGENS/. Acesso em 03 jul. 2015.

65 http://www.cnm.org.br/portal/images/stories/Links/ 28102014_OF_2720_14_Logstica_Reversa_MMA.protocolado.pdf. Acesso em: 03 jul. 2015.

${ }^{66} \mathrm{http} / / /$ residuossolidos.cetesb.sp.gov.br/wp-content/uploads/sites/36/2013/11/index.pdf.Acesso em: 03 jul. 2015. 
situação frente às determinações legais previstas no artigo 33, parágrafo $3^{\circ}$, incisos I a III da Lei 12.305/2010 vamos concluir que nenhuma destas opções de operacionalização do sistema foi acordada e, ainda que se alegue que a lei permita "outras medidas", por óbvio pressupõe que os custos sejam sempre arcados pelo setor empresarial, seja ele qual for.

Não há dúvida que os Municípios podem tomar a iniciativa de propositura de acordos setoriais ou termos de compromisso, conforme disposto no artigo 31, IV c.c. artigos 20 "caput" e 32 "caput" da PNRS, devendo, entretanto, observar as regras específicas do artigo 34, ou seja, os acordos e termos de compromissos firmados no âmbito nacional têm prevalência sobre os firmados em âmbito regional ou estadual, e estes sobre os firmados em âmbito municipal. Porém, na aplicação das regras concorrentes, os acordos firmados de menor abrangência geográfica podem ampliar, mas não abrandar, as medidas de proteção ambiental constantes nos acordos setoriais e termos de compromissos firmados com maior abrangência geográfica.

Ultrapassada a fase de eventual acordo por chamado público, outro instrumento já citado para a implantação da Logística Reversa é o Regulamento expedido pelo Poder Público, veiculado por decreto editado pelo Poder Executivo. ${ }^{67}$ Mais uma vez cabe frisar que, também relativamente a este instrumento, a PNRS não exclui a possibilidade do uso do decreto pelos Municípios.

O uso deste instrumento, a nosso ver, pressupõe que, tanto o acordo setorial, quanto o termo de compromisso (que são instrumentos que encerram um ato de natureza contratual, bilateral e um acordo de vontades, firmados após toda uma negociação em torno da implantação e operacionalização da logística reversa), não tenham sido celebrados, seja pelo fato do setor empresarial não responder ao chamamento através dos editais, seja pelo fato das propostas apresentadas não chegarem a um denominador comum.

De fato, dentre as competências do Chefe do Poder Executivo, encontra-se uma de substancial importância, qual seja, sua faculdade regulamentar. A atual Constituição Federal outorga referido poder ao Presidente da República em seu artigo 84, IV. O mesmo ocorre com os ocupantes de cargos simétricos nos âmbitos municipal e estadual.

Comentando sobre o tema, Carvalho (2002, p. 117-118) esclareceu em seu artigo "O decreto regulamentar como atividade legislativa do Poder Executivo" que

\footnotetext{
Os regulamentos, embora não integrem o rol do artigo 59 da Constituição Federal, são atos de caráter eminentemente normativo e, consequentemente, semelhantes à lei em seu aspecto material. Por sua vez, regulam um número imprevisível de situações, e revestem-se das características de abstração e generalidade, qualidades próprias das leis.
}

Ressalta-se: quando o Presidente da República edita medidas provisórias e leis delegadas, figuras previstas no mencionado artigo 59 da Carta Magna, exerce atividade legislativa primária. Ao expedir regulamentos, exerce atividade legislativa secundária.

Finalmente, para lançar mão de quaisquer dos instrumentos citados, considerando as bases fixadas pela PNRS, que indicam toda uma sistemática a ser seguida, como publicação de editais de chamamento, após prévia aprovação pelo Comitê Orientador; avaliação da viabilidade técnica e econômica da implantação da logística reversa, promovida por um grupo técnico avaliação das propostas; publicação das propostas mediante audiência pública, é recomendável que os Municípios regulamentem estas questões através de legislação municipal própria, dando suporte a qualquer iniciativa de sua parte, criando também seu Comitê Orientador, indicando

${ }^{67}$ Decreto 7.404/2010, arts. 15, II, 30 e 31. 
sua composição, atribuições, aprovando seu regimento interno e também fixando a competência pelas Secretarias ou Departamentos de Meio Ambiente para avaliação das propostas.

É sabido que, pela Constituição Federal, em seu art. 24, VI e VIII, a competência legislativa em matéria ambiental é concorrente, ficando a cargo da União a elaboração de normas gerais e aos demais entes federativos as normas de caráter suplementar. Igualmente, a competência material, de acordo com o art. 23, VI e VIII, da CF, é comum, cabendo a todos (União, Estados e municípios) adotar medidas protetivas em igualdade, não restando, assim, dúvida que poderá legislar sobre logística reversa em âmbito local.

\section{CONCLUSÕES}

O crescente aumento da população em áreas urbanas, o estilo de vida da sociedade contemporânea e as estratégias de marketing do setor produtivo levam a um consumo intensivo e, por consequência, cada vez mais a geração de resíduos sólidos. Como, via de regra, as cidades não acompanharam com a mesma rapidez este crescimento, com a oferta de uma infraestrutura adequada para a gestão dos resíduos sólidos, o resultado disso é uma série de impactos ambientais à saúde pública e social incompatíveis com o modelo de desenvolvimento sustentável.

Para permitir que o País avançasse no enfrentamento dos principais problemas acima mencionados e decorrentes do manejo inadequado dos resíduos sólidos, foi editada a PRNS que tem como espinha dorsal a prevenção e a redução na geração de resíduos, tendo como proposta a prática de hábitos de consumo sustentável, além de um conjunto de instrumentos para propiciar o aumento da reciclagem e da reutilização dos resíduos sólidos (aquilo que tem valor econômico e pode ser reciclado ou reaproveitado) e a destinação ambientalmente adequada dos rejeitos (aquilo que não pode ser reciclado ou reutilizado). Dentre esses instrumentos, a Logística Reversa relacionada à implantação da responsabilidade compartilhada dos geradores de resíduos: [...] fabricantes, importadores, distribuidores, comerciantes, [...] cidadãos e titulares de serviços de manejo dos resíduos sólidos urbanos, que se mostra como um dos caminhos para que o País consiga, de fato, cumprir a meta prevista e não cumprida de eliminação dos "lixões" e impõe ao setor empresarial as obrigações previstas nos artigos 31 a 33 da PNRS.

Os benefícios da Logística Reversa não são apenas de cunho ambiental e de saúde pública, já que proporcionam o reaproveitamento dos produtos e embalagens que são descartados, por meio de reformas ou reciclagem, inserindo o resíduo novamente no processo de produção como matéria-prima, evitando o descarte irregular, com todos os problemas de saúde pública decorrentes, a poluição e a utilização de matéria prima. Ela também traz ao setor empresarial benefícios de ordem financeira, na medida em que há economia e ganhos obtidos com o reaproveitamento de materiais, utilização de embalagens retornáveis e venda de resíduos no mercado secundário, como também agrega valor à sua imagem corporativa, sendo sua prática um diferencial em relação à concorrência. Através de uma postura ambiental correta, a empresa pode influenciar a relação com os clientes e sociedade. Exemplo bem-sucedido citado é o da indústria da reciclagem de alumínio.

As iniciativas sobre o assunto por parte da União e Estados-membros não tem sido suficientes para que os Municípios brasileiros tenham um prognóstico favorável no sentido de serem totalmente contemplados pelo sistema de Logística Reversa. As regras que vem sendo acordadas ignoram a participação dos Municípios nas discussões e impõem limites populacionais para que sejam contemplados, indo de encontro ao que a lei determina. Por isso, como os Municípios possuem legitimidade concorrente para legislar sobre matéria ambiental e também 
legitimidade para assinar acordos e termos, estabelecendo a logística reversa com os geradores dos resíduos listados no artigo 33 da Lei 12.305/2010, ( ) devem ter uma postura proativa, mediante prévia edição de lei municipal e decreto que regulamente o processo envolvendo a Logística Reversa nos Municípios, criando seus respectivos comitês orientadores, fixando os procedimentos para os editais de chamamento dos acordos setoriais e termos de compromissos, possibilidade de uso do regulamento (decreto) para sua implantação, etc.

E, para finalizar, na busca da efetiva implantação da PNRS e na determinação do modo como os Municípios devem cumprir o seu papel, o Ministério Público dos Estados é um indispensável ator. Através da Promotoria de Justiça de Meio Ambiente ou Grupos de Atuação Especial na matéria, podem atuar de ofício, ou podem ser acionados para que fiquem atentos, não só ao conteúdo mínimo dos Planos Municipais de Gestão Integrada de Resíduos Sólidos, previsto no art. 19 da Lei 12.305/2010, como também acompanhar, orientar e cobrar dos Municípios a tomadas de decisões que possam tornar efetivas as disposições da PNRS relativas à Logística Reversa em seus respectivos territórios, de modo a se exigir do setor empresarial o cumprimento de suas obrigações, sem oneração dos cofres públicos municipais. Em caso de omissões dos Municípios quanto ao poder/dever de agir e defender o meio ambiente e os cofres públicos, cabe aos Promotores de Justiça, através da instauração de inquéritos civis, exigir a implantação e operacionalização da Logística Reversa dos responsáveis, apurar os fatos visando buscar uma solução acordada através do termo de ajustamento de conduta, que também é apontado pelo art. $8^{\circ}$ da Lei 12.305/2010 como um instrumento de implantação da PNRS, ou, em último caso, a judicialização da questão em face dos Municípios e setores empresariais omissos.

\section{REFERÊNCIAS}

ASSOCIAÇÃO BRASILEIRA DE ALUMÍNIO. Disponível em: <http://www.abal.org.br/ noticias/lista-noticia/integra-noticia/?id=359>. Acesso em: 03 jul. 2015.

ABRELPE. Panorama dos resíduos sólidos em 2014, 2015. Disponível em: http:// www.abrelpe.org.br/panorama_envio.cfm?ano=2014. Acesso em: 25. jul.2017.

BRASIL. Lei n. 12.305, de 02 de agosto de 2010. Institui a Política Nacional de Resíduos Sólidos; altera a Lei no 9.605, de 12 de fevereiro de 1998; e dá outras providências. http:// www.mma.gov.br/port/conama/legiabre. cfm?codlegi=636.

BRASIL. Decreto 7.404, de 23 de dezembro de 2010. Regulamenta a Lei no 12.305, de 2 de agosto de 2010, que institui a Política Nacional de Resíduos Sólidos, cria o Comitê Interministerial da Política Nacional de Resíduos Sólidos e o Comitê Orientador para a Implantação dos Sistemas de Logística Reversa, e dá outras providências. http://www.mma.gov.br/port/conama/ legiabre.cfm?codlegi $=636$.

BRASIL. Decreto 9.177/2017, de 23 de outubro de 2017. Regulamenta o art. 33 da Lei $\mathrm{n}^{\circ}$ 12.305, de 2 de agosto de 2010, que institui a Política Nacional de Resíduos Sólidos, e complementa os art. 16 e art. 17 do Decreto $n^{\circ} 7.404$, de 23 de dezembro de 2010 e dá outras providências. http://www.planalto.gov.br/ccivil_03/_ato2015-2018/2017/decreto/D9177.htm.

CARVALHO, Marcelo. O decreto regulamentar como atividade legislativa do poder executivo. Revista Jurídica “9 de Julho", São Paulo, n. 1, p. 117-128, 2002. Disponível em: http:// www.al.sp.gov.br/repositorio/bibliotecaDigital/358_arquivo.pdf.. Acesso em: 03 jul. 2015. 
CETESB. Relação de acordos setoriais, 2017. Disponível em: <http:// residuossolidos.cetesb.sp.gov.br/wp- content/uploads/sites/36/2013/11/index.pdf>. Acesso em: 26 jul. 2017.

CONFEDERAÇÃO NACIONAL DOS MUNICÍPIOS. Disponível em: <http:// www.cnm.org.br/portal/images/stories/Links/28102014_OF_2720_14. protocolado.pdf>. Acesso em: 03 jul. 2015.

IBGE. Estatística/população/estimativa, 2014. Disponível em: <http://www.ibge.gov.br/ home/estatistica/populacao/estimativa2014/default.shtm〉>. Acesso em: 25 jul. 2017.

IBGE. Estatística/população/projeção, 2013. Disponível em: <http://www.ibge.gov.br/home/ estatistica/populacao/projecao_da_populacao/2013/default_tab.shtm>. Acesso em: 25 jul. 2017.

IBGE. Censo, 2010. Disponível em: $<$ http://www.censo2010.ibge.gov.br/sinopse/index. php?dados=29\&uf=35>. Acesso em: 25. jul. 2017.

LEMOS, Patrícia Faga Iglesias. Resíduos Sólidos e Responsabilidade Pós-consumo. São Paulo: Revista dos Tribunais, 2014.

MILARÉ, Edis. Direito do Ambiente. 8. ed., revista, atualizada e ampliada. São Paulo: Revista dos Tribunais, 2013.

MINISTÉRIO DO MEIO AMBIENTE - MMA. Plano Nacional de Resíduos Sólidos. Brasília: MMA, 2012. Disponível em: <http://www.sinir.gov.br/documents/10180/12308/ PNRS_Revisao_Decreto_280812.pdf> Acesso em: 26 jul. 2017.

PAGANI POSSAMAI, Fernando e Outros. Lixões inativos na região carbonífera de Santa Catarina: análise dos riscos à saúde pública e ao meio ambiente. Revista Ciência \& Saúde Coletiva, vol. 12, núm. 1, janeiro-março, 2007.

SILVA FILHO, Carlos Roberto da e SOLER, Fabrício Dorado. Gestão de Resíduos Sólidos. O que diz a lei. São Paulo: Editora Trevisan, 2012.

SISINNO, CLS. (org.) Resíduos sólidos, ambiente e saúde: uma visão multidisciplinar. Rio de Janeiro: Editora FIOCRUZ, 2000.

SINIR. Proposta de acordo setorial de embalagens, 2015. Disponível em: <http:// sinir.gov.br/documents/10180/17496/PROPOSTA_ACORDO_SETORIAL_EMBALAGENS/ >. Acesso em 03 jul. 2015.

Recebido em: 5 nov. 2017.

Aceito em: 28 mar. 2018. 